\title{
Analysis of interleukin- 4 and interleukin-10 and their association with the lymphocytic infiltrate in the small intestine of patients with coeliac disease
}

\author{
C G Beckett, D Dell'Olio, M Kontakou, R T Przemioslo, S Rosen-Bronson, P J Ciclitira
}

\begin{abstract}
Background-Concentrations of proinflammatory cytokines are raised in the small intestine of patients with coeliac disease after ingestion of gluten but there are equivalent data on interleukin-4 (IL-4) and interleukin-10 (IL-10) producing cells. These cytokines are known to exert important regulatory effects on proinflammatory cytokine production from lymphocytes and macrophages.

Aims-To investigate whether there is a primary deficiency of IL-4 and IL-10 producing cells and their site of production in the small intestine of patients with coeliac disease in relation to the changes in inflammatory cell infiltrate.

Patients-Jejunal biopsy specimens from patients with coeliac disease (11 untreated, 10 treated) and nine disease controls were studied.
\end{abstract}

Methods-Immunohistochemical staining of sections for IL-4 and IL-10 cytokines and the cell phenotypic markers CD3 (T lymphocytes) and CD45 (total inflammatory cell infiltrate) was carried out using monoclonal antibodies. Expression of IL-4 and IL-10 messenger RNA was detected by in situ hybridisation with oligonucleotide probe cocktails for each cytokine.

Results-IL-4 and IL-10 mRNA and protein were detected in the lamina propria of treated and untreated coeliac patients and disease controls but not in the epithelium. A significant increase in the number of CD45 $(p<0.005)$ and CD3 $(p<0.05)$ positive cells was found in the lamina propria of patients with untreated coeliac disease compared with treated coeliac patients and disease controls but there were no differences in IL-4 or IL-10 between these groups with either method.

Conclusions-There is no primary deficiency of IL-4 and IL-10 producing cells in the small intestine of patients with coeliac disease. Detectable concentrations of IL-4 and IL-10 were found in control patients which suggests that these cytokines are involved in normal mucosal immunoregulation. The increased number of T lymphocytes but not IL-4 or IL-10 producing cells in the lamina propria of patients with untreated than in those with treated disease suggests not only that the lamina propria is the major mucosal compartment for cytokine production but that newly recruited mucosal $T$ lymphocytes are directed to a predominant $\mathrm{Th} 1$ and not a Th2 cytokine response in coeliac patients on a diet containing gluten.

(Gut 1996; 39: 818-823)

Keywords: coeliac disease, interleukin-4, interleukin-10, lymphocytes.

Coeliac disease is a gluten induced enteropathy that occurs in genetically predisposed subjects. The lesions found in the small intestine of patients affected consists of villus flattening and crypt cell hyperplasia. ${ }^{1}$ These changes revert towards normal on removal of gluten from the diet. There is mounting evidence that $T$ lymphocytes are central to the disorder ${ }^{2}$ and that the production of cytokines by inflammatory cells, especially $T$ cells and macrophages, are responsible for the histological changes.

$T$ lymphocytes can be defined according to the profile of cytokines that they secrete. ${ }^{3}$ This has been clearly shown in murine $\mathrm{T}$ cells but is less obvious in human tissue ${ }^{4}$ : however, it is still a useful way of delineating cytokine responses. The Th1 response is predominantly of interferon- $\gamma$ (IFN- $\gamma$ ) and interleukin-2 (IL-2) and drives cell mediated responses whereas the Th2 cytokines, which include IL-4 and IL-10, control antibody mediated processes. Th0 cells are characterised by the production of cytokines of both $\mathrm{Th} 1$ and $\mathrm{Th} 2$ types and are thought to be precursors of the Th1 and Th2 cells. These cytokines exert regulatory effects on each other which may be important in disease states.

A role for IL-4 and IL-10 in gastrointestinal disease is suggested by the fact that IL-10 knockout mice develop a chronic enterocolitis. $^{5}$ There are also reduced numbers of IL-4 secreting cells in the intestine of children with inflammatory bowel disease. ${ }^{6}$

In coeliac disease it has already been shown that there is a Th1 response with increased concentrations of the cytokines IL-2 and IFN- $-\gamma^{7}$ as well as IL-6 and tumour necrosis factor- $\alpha$ (TNF- $\alpha$ ), which are predominantly produced by macrophages ${ }^{9}$ in the lamina propria of patients with the untreated condition. These findings have been reinforced by the fact that gluten specific HLA-DQ restricted $T$ cells have been isolated from the small intestine of patients with coeliac disease. ${ }^{10}$ Supernatant fluids from these $\mathrm{T}$ cell clones activated with gluten caused a reduction in 
enterocyte height - an indicator of epithelial cell damage - when cultured with normal small intestinal biopsies and this effect could be blocked with anti-TFN- $\gamma$ antibodies. ${ }^{11}$ These findings raise the possibility that a lack of regulatory cytokines could be responsible for raised concentrations of proinflammatory cytokines in response to gluten in patients with coeliac disease.

The aim of the study was to investigate IL-4 and IL-10 mRNA expressing and protein producing cells in the small intestine of patients with treated and untreated coeliac disease compared with disease controls in relation to the changes in inflammatory cells, particularly $T$ lymphocytes.

These experiments should show whether there is a primary deficiency of these regulatory cytokines in coeliac disease and identify their site of production. They should also permit the dissection of the balance of Th1 and Th2 cytokine profiles in the mucosa of the small intestine of patients with coeliac disease and their change in response to a diet containing gluten.

\section{Patients and methods \\ The patient groups comprised of following:}

Untreated coeliac disease

Eleven adult patients were studied (eight women, three men, mean age $38 \cdot 2$, range $16-67$ ).

\section{Treated coeliac disease}

Ten adult patients were studied (seven women, three men, mean age $47 \cdot 6$, range 24-84). These patients had been shown to have pathological changes in biopsy sections of the small intestine consistent with a diagnosis of coeliac disease which later improved after at least six months of treatment with a gluten free diet (according to the European Society for Paediatric Gastroenterology criteria ${ }^{12}$ ).

\section{Control group}

Nine adult patients were studied (five women, four men, mean age $45 \cdot 5$, range $24-74$ ). These had undergone biopsy of the small intestine as part of routine investigation and had a final diagnosis of irritable bowel syndrome with normal histology.

\section{BIOPSY SPECIMENS}

Three biopsy specimens were obtained from the second part of the duodenum, with an Olympus IT 20 endoscope using FK 13 forceps $(8 \mathrm{~mm})$. One specimen was fixed in formalin whereas the other two specimens were oriented villous side uppermost, coated in Optimum Cutting Compound (Cryo-M-bed; Bright's Huntington, UK), snap frozen in isopentane cooled in liquid nitrogen, and stored in liquid nitrogen until processed. At least 12 cryostat sections were cut at $5 \mu \mathrm{m}$ on a Bright's open top cryostat at $-20^{\circ} \mathrm{C}$ and collected on to glass slides that had been washed with distilled water rendered RNAase free by diethylpyrocarbonate (DEPC) treatment and precoated with polyL-lysine. Sections were briefly fixed in acetone for five minutes and stored at $-20^{\circ} \mathrm{C}$.

\section{IMMUNOHISTOCHEMISTRY}

Sequential sections were stained in duplicate with an indirect immunoperoxidase technique. They were fixed in acetone, preincubated with $0 \cdot 1 \%$ sodium azide $/ 0.3 \%$ hydrogen peroxide for 10 minutes, then normal rabbit serum for 20 minutes to block endogenous peroxidase staining, $0.01 \%$ avidin for 20 minutes, and $0.01 \%$ biotin for 10 minutes to block endogenous biotin. The primary layer antibodies were then added and the mixture incubated for one hour at room temperature. The primary monoclonal antibodies used underwent initial titration experiments to determine the optimal dilution of each antibody. The following were used.

(a) Murine monoclonal antihuman CD45 (Serotec MCA669) at 1:200 dilution. This recognises the common leucocyte antigen but not haemopoetic cells and gives an estimate of total inflammatory cell infiltrate.

(b) Murine monoclonal antihuman CD3 (Dako M0835) at 1:80 dilution. This recognises $T$ lymphocytes. The cell phenotype antibodies were diluted with phosphate buffered saline (PBS).

(c) Murine monoclonal antihuman IL-4 (Serotec MCA952) at 1:75 dilution.

(d) Murine monoclonal antihuman IL-10 (Serotec MCA1110) at 1:400 dilution. The cytokine antibodies were diluted in a $5 \%$ solution of foetal calf serum.

The secondary layer comprised biotinylated rabbit antimouse immunoglobulins (Dako E354) at 1:200 dilution for 30 minutes. The tertiary layer comprised avidin-biotin complex (Dako K391) at 1:100 dilution for a further 30 minutes. A further step was used between the secondary and tertiary layers which involved treatment with $0.5 \mathrm{mg} / \mathrm{ml}$ glucose oxidase for 30 minutes at $37^{\circ} \mathrm{C}$ in glucose stock solution which blocked non-specific staining of eosinophils. After 10 minutes of treatment with aminoethyl carbazole (Sigma A6926) the cells were counterstained with Mayer's haematoxylin and mounted with glycerol mounting medium. Sections were thoroughly washed with PBS between steps.

The controls omitted the primary antibody and used a murine monoclonal antibody WB6/8 (1:20 dilution) raised against a gliadin peptide, of the same isotype as the antihuman antibodies employed.

\section{IN SITU HYBRIDISATION}

DNA oligonucleotide probes were obtained commercially ( $R$ and $D$ systems). Cytokine mRNA detection was achieved with a cocktail of three probes for each cytokine, each 30 bases long, with cDNA sequences coded by three different exon regions of the IL-4 (BPR 22) and IL-10 (BPR 237) genes. 
Each oligonucleotide (4 pmol) was labelled by the addition of an a ${ }^{35} \mathrm{~S}$ dATP 'tail' to the $3^{\prime}$ termini using terminal deoxynucleotidyl transferase, according to the supplier's protocol (Promega). After the labelling reaction, probes were purified by filtration through Sephadex G-50 DNA grade columns (Pharmacia) and their specific activity measured with a Rackbeta liquid scintillation counter. The specific activity was measured with a Rackbeta liquid scintillation counter. The specific activity of the probes was greater than $1 \times 10^{8} \mathrm{cpm} / \mu \mathrm{g}$.

All solutions were prepared with DEPC treated water. Fixation was with $4 \%$ (w/v) paraformaldehyde (PFA) in PBS pH 7.4 for 15 minutes, followed by two washes in $15 \%$ (w/v) sucrose in PBS for 10 minutes each. Pretreatments were $(a) 0.3 \%(\mathrm{v} / \mathrm{v})$ Triton-X-100 in PBS for 10 minutes, (b) $1 \mu \mathrm{g} / \mathrm{ml}$ proteinase $\mathrm{K}$ for 30 minutes at $37^{\circ} \mathrm{C}$, (c) postfixation in $0.4 \%$ (w/v) PFA for 10 minutes, and (d) $0.1 \mathrm{M}$ triethanolamine containing $0.25 \%(\mathrm{v} / \mathrm{v})$ acetic anhydride for 10 minutes. Duplicate sections were prehybridised in a mixture of $2 \times$ salinesodium citrate buffer (SSC), $50 \%$ (v/v) formamide, and $1 \times$ Denhardt's solution at $37^{\circ} \mathrm{C}$ for one hour and then hybridised overnight with $2 \mathrm{ng}$ labelled probe at $37 \eta \mathrm{C}$ in a solution containing: $2 \times \mathrm{SSC}, 50 \%$ (v/v) formamide, $0.4 \mathrm{mg} / \mathrm{ml}$ denatured sheared salmon sperm DNA, and $10 \%$ (w/v) dextran sulphate. Posthybridisation washes were carried out at $39^{\circ} \mathrm{C}$, for 30 minutes each, in $2 \times S S C, 1 \times S S C+50 \%$ formamide, and $0 \cdot 1 \times \mathrm{SSC}$. Sections were dehydrated serially in $60 \%, 90 \%$, and $95 \%$ ethanol and dried at room temperature. Autoradiography consisted of dipping sections in Ilford K5 photographic gel emulsion that had been diluted 1:1 in prewarmed distilled water. The sections were left to dry in a dark room for about two hours and then incubated at $4^{\circ} \mathrm{C}$ in a lightproof box containing silica gel for five days. Slides were developed in $4.4 \%(w / v)$ Dektol solution (Kodak) for two minutes, washed briefly in distilled water, and fixed in $30 \%(w / v)$ sodium thiosulphate at $4^{\circ} \mathrm{C}$ for 15 minutes. Finally the slides were thoroughly rinsed in running tap water and counterstained with Mayer's haematoxylin.

Slides treated with either RNAase-free DNAase (no effect on hybridisation) or DNAase-free RNAase (no hybridisation) were used as controls. After the proteinase $\mathrm{K}$ treatment, sections were incubated at $37^{\circ} \mathrm{C}$ with either of the two enzymes at a concentration of $100 \mathrm{mg} / \mathrm{ml}$ for 30 minutes.

Oligonucleotides containing sequences complementary to the cytokine probes (sense probes) were used as negative controls. An

TABLE I Number of CD45 and CD3 staining cells in the lamina propria of untreated and treated coeliac patients and control patients

\begin{tabular}{lll}
\hline Patient group & $C D 45$ & $C D 3$ \\
\hline Coeliac disease: & & \\
$\quad$ Untreated & $111 \cdot 8(105 \cdot 5-154 \cdot 2)^{\star \star}$ & $96(66 \cdot 5-104)^{\star}$ \\
$\quad \begin{array}{l}\text { Treated } \\
\text { Controls }\end{array}$ & $\begin{array}{l}81 \cdot 6(66 \cdot 6-87 \cdot 5)^{\star \star} \\
43 \cdot 5(34 \cdot 7-57 \cdot 4)\end{array}$ & $\begin{array}{l}72 \cdot 5(31 \cdot 5-78 \cdot 8)^{\star} \\
\text { (36-59.1) }\end{array}$
\end{tabular}

Values are median/unit area (interquartile range)

${ }^{\star} \mathrm{p}<0.05 ;{ }^{\star} \mathrm{p}<0.005 v$ control group. oligo dT probe was also used for the detection of total mRNA as a positive control.

OUANTIFICATION AND STATISTICAL ANALYSIS All assessments were performed by two observers who were blinded to patient identity and cytokine/cell phenotype. The number of positive cells within the lamina propria were counted per unit area with an eyepiece graticule under $\times 400$ magnification. The lamina propria was assessed from the tip of the villus down to the deeper lamina propria on duplicate sections for each cytokine/cell phenotype. The eyepiece graticule consisted of 100 squares which enabled the villous lamina propria to be counted as a fraction of a complete grid and it enabled the avoidance of crypt epithelium in the deeper lamina propria. In total, at least five complete graticule areas were counted per section. The results were expressed as the median number of positive cells in the lamina propria per unit area $\left(0.02 \mathrm{~mm}^{2}\right)$ in each patient group. Statistical analysis was by Mann-Whitney $U$ test. Significance was set at $\mathrm{p}<0.05$.

The study was approved by the hospital ethics committee in accordance with the Declaration of Helsinki.

\section{Results}

Figures 1 and 2 show examples of IL-10 immunohistochemical staining and IL-4 messenger RNA expression respectively in the lamina propria.

CELL PHENOTYPE (TABLE I)

The lamina propria of the untreated coeliac group had a significantly increased number of CD45 staining cells representing the total inflammatory cell infiltrate ( $111 \cdot 8 /$ unit area) compared with both the treated coeliac group (81.6/unit area) and disease controls (43.5/unit area) ( $<<0.005$ each). The total number of $T$ lymphocytes (CD3) was also increased in the lamina propria of patients with untreated coeliac disease (96/unit area) compared with treated coeliac and control groups $(71.0$ and 42.5 /unit area respectively) $(\mathrm{p}<0.05$ each).

INTERLEUKIN-4 (TABLE II)

In the lamina propria of the untreated coeliac group the number of cells expressing product or message (5.4 and $8 \cdot 8$ /unit area respectively) was not significantly different from the treated coeliac ( 8.6 and $7 \cdot 2$ /unit area) and disease control ( $4 \cdot 4$ and $7 \cdot 3$ /unit area) groups.

INTERLEUKIN-10 (TABLE II)

There were no significant differences in the number of cells expressing product or message between the untreated coeliac $(4 \cdot 3$ and $8 \cdot 8 /$ unit area respectively), the treated coeliac ( 6.2 and $9 \cdot 6 /$ unit area), and the disease control ( 4.9 and $8 \cdot 8 /$ unit area) groups. 


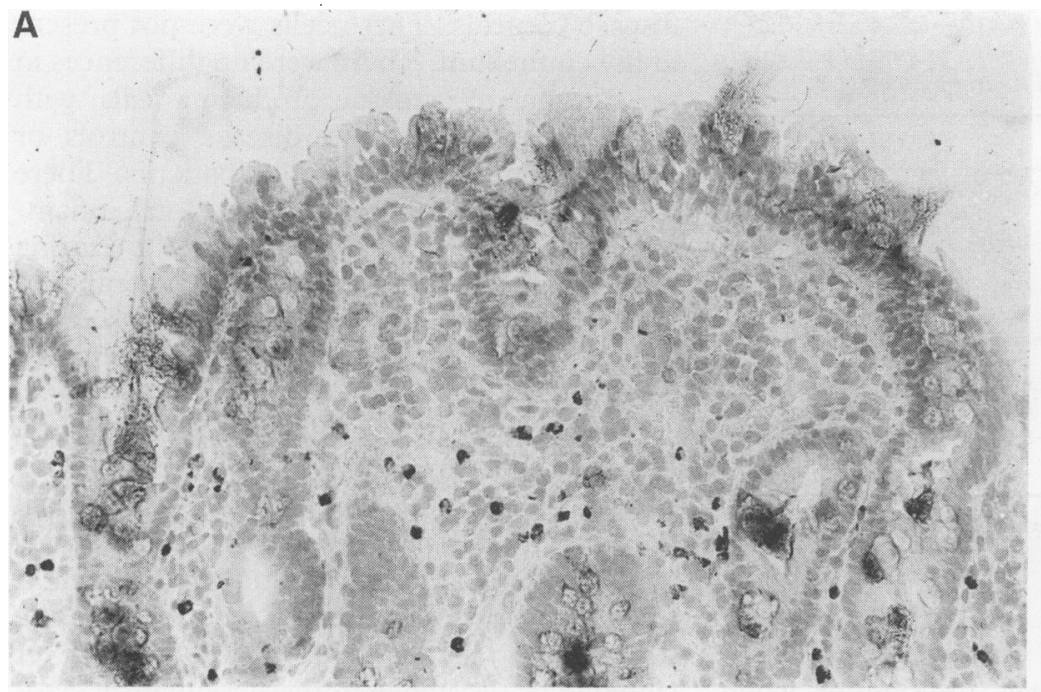

Figure 1: Photomicrographs of IL-10 immunohistochemical staining in (A) untreated,

(B) treated coeliac disease. The non-cellular goblet cell staining is clearly distinguished from the cytokine staining in the lamina propria (originally $\times 200$ ).
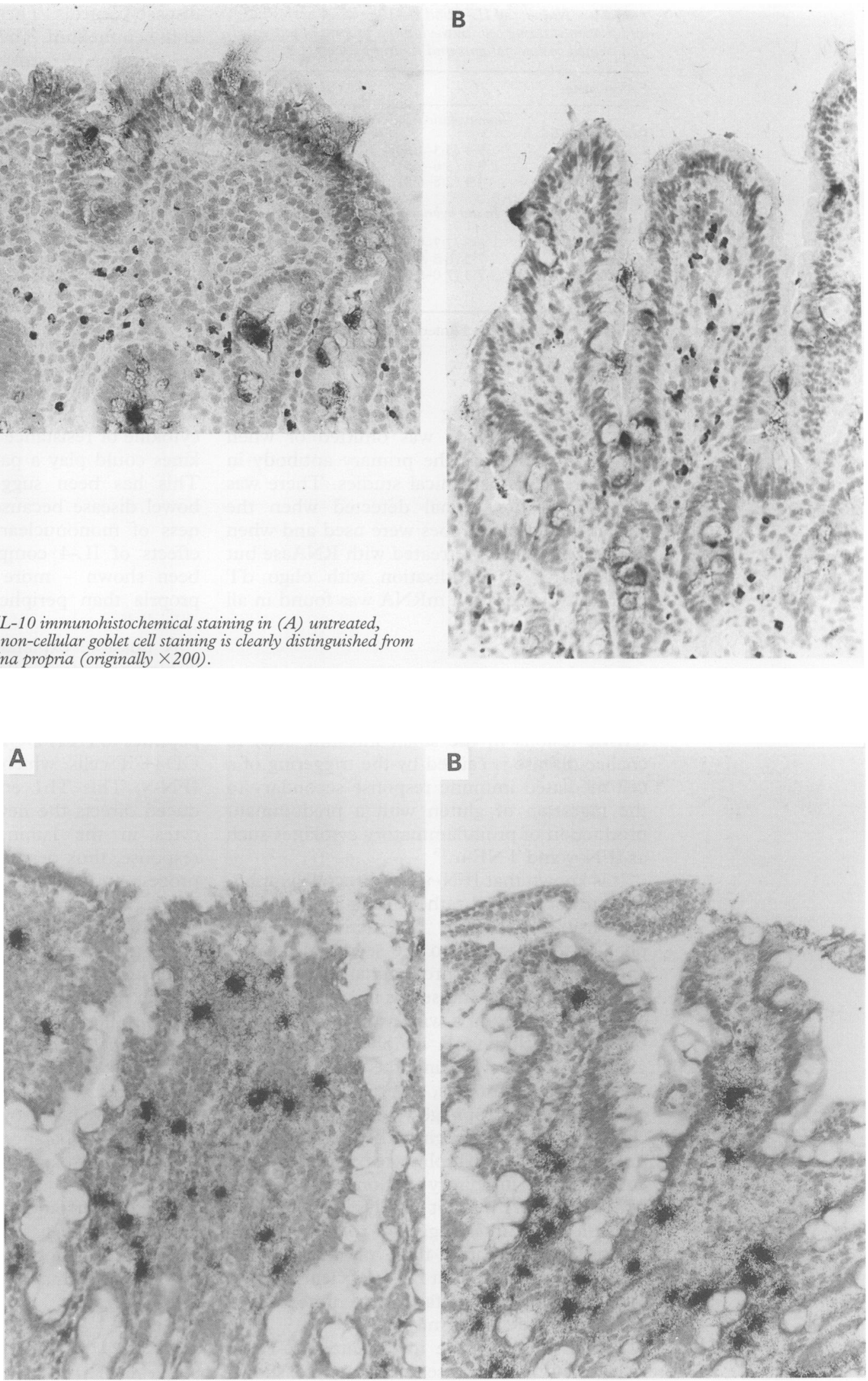

B

The study was focused on events in the lamina propria of patients with coeliac disease. There was staining of CD45 and CD3 cells in the epithelium (results not shown), however, there was virtually no cytokine staining in the epithelium with either method used and so it was not possible to submit epithelial cytokine staining to statistical analysis. There was some non-cellular goblet cell staining with the immunohistochemistry method which was clearly distinguishable from the specific staining. 
TABLE II Number of $I L-4$ and IL-10 $m R N A$ expressing and protein staining cells in the lamina propria of untreated and treated coeliac patients and control patients

\begin{tabular}{lcc}
\hline Patient group & $I L-4$ & $I L-10$ \\
\hline Coeliac disease: & Immunohistochemistry & \\
$\quad$ Untreated & $5 \cdot 4(3 \cdot 3-10 \cdot 9)$ & $4 \cdot 3(2 \cdot 1-8 \cdot 1)$ \\
$\quad \begin{array}{l}\text { Treated } \\
\text { Controls }\end{array}$ & $8 \cdot 6(3 \cdot 6-9 \cdot 5)$ & $6 \cdot 2(3 \cdot 0-9 \cdot 4)$ \\
& $4 \cdot 4(2 \cdot 8-6 \cdot 0)$ & $4 \cdot 9(2 \cdot 8-6 \cdot 0)$ \\
& In situ hybridisation & \\
Coeliac disease: & & \\
$\quad$ Untreated & $8 \cdot 8(7 \cdot 7-9 \cdot 6)$ & $8 \cdot 8(8 \cdot 6-11 \cdot 3)$ \\
$\quad$ Treated & $7 \cdot 2(6 \cdot 5-9 \cdot 7)$ & $9 \cdot 6(7 \cdot 2-11 \cdot 3)$ \\
Controls & $7 \cdot 3(7 \cdot 0-8 \cdot 0)$ & $8 \cdot 8(7 \cdot 8-9 \cdot 6)$ \\
& & \\
\hline
\end{tabular}

Values are median/unit area (interquartile range).

\section{CONTROLS}

No positive staining was detected when the primary antibody was omitted or when WB6/8 was used as the primary antibody in the immunohistochemical studies. There was no hybridisation signal detected when the ${ }^{35} \mathrm{~S}$-labelled sense probes were used and when the sections were pretreated with RNAase but not DNAase. Hybridisation with oligo dT probes to detect total mRNA was found in all biopsies.

\section{Discussion}

There is mounting evidence that the characteristic lesions in the small intestine seen in coeliac disease is caused by the triggering of a cell mediated immune response secondary to the ingestion of gluten with a predominant production of proinflammatory cytokines such as IFN- $\gamma$ and TNF- $\alpha{ }^{13}$

It is known that IFN- $\gamma$ can direct $\mathrm{T}$ lymphocytes towards a Th1 rather than a Th2 cytokine response and IFN- $\gamma$ can activate macrophages, thus leading to the secretion of IL-6 and TNF- $\alpha$. IL-4 is predominantly produced by $\mathrm{T}$ lymphocytes and seems to have opposing effects to IFN- $\gamma$ on a wide variety of immune functions including B lymphocyte immunoglobulin isotype switching, the development of $\mathrm{T}$ cell cytokine profiles, and several functional activities of macrophages. ${ }^{14} \mathrm{IL}-10$ is another cytokine which is thought to be predominantly produced by $T$ lymphocytes and to exert considerable inhibitory actions on macrophages and Th1 but not Th2 lymphocytes. ${ }^{15}$

Depletion studies suggest a role for IL-4 in the early proliferative form of murine graft versus host disease ${ }^{16}$ but IL-4 deficient mice do not develop a spontaneous enteropathy, ${ }^{17}$ unlike IL-10 deficient mice. ${ }^{5}$

Several studies have investigated IL-10 in inflammatory bowel disease. Some have shown raised concentrations of IL-10 in active disease compared with controls ${ }^{18}{ }^{19}$; others showed no changes $^{20}$ although IL-10 down regulated proinflammatory cytokine production from lamina propria mononuclear cells in vitro and in vivo after topical administration as well as an endoscopic improvement of refractory distal colitis.

In our study, we have shown the presence of IL-4 and IL-10 mRNA and protein producing cells in the lamina propria of patients with untreated and treated coeliac disease as well as disease controls. These cells were not present in the epithelium. There were no differences in the number of cytokine producing cells, with either method used, in disease controls or untreated and treated coeliac patients. There was a significant increase in the total inflammatory cell infiltrate (CD45) in the lamina propria of untreated coeliac patients compared with treated coeliac patients and disease controls and most of these cells were $T$ lymphocytes (CD3).

Our findings suggest that there is no primary deficiency in expression of IL-4 or IL-10 in coeliac disease; they are detected in normal mucosa, and they are probably involved in maintaining normal intestinal immunoregulation. It remains a possibility that as we are detecting cytokine producing cells, a relative lack of cytokine or resistance to these regulatory cytokines could play a part in disease expression. This has been suggested for inflammatory bowel disease because a reduced responsiveness of mononuclear cells to the inhibitory effects of IL-4 compared with controls has been shown - more pronounced in lamina propria than peripheral blood mononuclear cells. ${ }^{2122}$

A possible explanation for the changes in $\mathrm{T}$ lymphocytes in relation to cytokine profiles in coeliac disease is proposed. The ingestion of gluten results in the presentation of 'toxic' peptides to HLA DQ2 specific gliadin sensitive CD4+ $\mathrm{T}$ cells, which predominantly produce IFN- $\gamma$. This Th1 environment initially produced directs the newly recruited $\mathrm{T}$ lymphocytes in the lamina propria to the Th1 response, thus perpetuating the inflammatory process and the development of the mucosal lesion. This is supported by the fact that gliadin specific $T$ cell clones derived from peripheral blood produce a Th 0 cytokine profile whereas clones derived from the small intestine of coeliac patients produce more of a Th1 cytokine profile. ${ }^{23} 24$ There is evidence that HLA restriction ${ }^{25}$ and the structure of the toxic epitope exert an influence on the $T$ cell cytokine profile. ${ }^{26}$

The study has provided further information regarding the balance of proinflammatory and regulatory cytokines in the small intestine of patients with coeliac disease which will help in the understanding of how cytokines are involved in the pathogenesis of the lesions in the small intestine in coeliac disease and other chronic inflammatory conditions of the gastrointestinal tract.

The study was supported by grants from St Thomas' Hospital Research (Endowments) Committee, the Nutricia UK Ltd, Semper AB, the Jean Shanks Research Foundation, and the National Institutes of Health (RO1 DK47716).

We thank Mr J M Nelufer for his technical support

Part of the study was presented at the Autumn meeting of the British Society of Gastroenterology, Coventry 1995.

1 Marsh M. The morphology and immunopathology of the jejunal lesion in gluten sensitivity. Eur $\mathcal{F}$ Gastroenterol Hepatol 1991; 3: 163-8.

2 MacDonald T, Spencer J. Evidence that activated mucosal $T$ cells play a role in the pathogenesis of enteropathy in human small intestine. $\mathcal{F}$ Exp Med 1988; 167: 1341-9.

3 Mosmann T, Cherwinski $H$, Bond $M$, Giedlin $M$ Coffman $R$. Two different types of murine $T$ cell clone. Definition according to profiles of lymphokine activities and secreted proteins. 7 Immunol 1986; 136: 2348-57. 
4 Kelso A. Th1 and Th2 subsets: paradigms lost? Immunology Today 1995; 16: 374-9.

5 Kuhn R, Lohler J, Rennick D, Rajewsky K, Muller W. Interleukin-10 deficient mice develop chronic enterocolitis. Cell 1993; 75: 263-74.

6 Karttunnen R, Breese E, Walker-Smith J, MacDonald T. Decreased mucosal interleukin-4 (IL-4) production in gut inflammation. $\mathcal{f}$ Clin Pathol 1994; 47: 1015-8.

7 Kontakou M, Sturgess R, Przemioslo R, Limb G, Nelufer J, Ciclitira $P$. Detection of interferon gamma mRNA in the mucosa of patients with coeliac disease by in situ hybridisation. Gut 1994; 35: 1037-41.

8 Kontakou M, Przemioslo R, Sturgess R, Limb A, Ciclitira P. Expression of tumour necrosis factor- $\alpha$, interleukin- 6 and interleukin-2 mRNA in the jejunum of patients with coeliac disease. Scand $\mathcal{F}$ Gastroenterol 1995; 30: $456-63$.

9 Przemioslo R, Kontakou M, Nobili V, Ciclitira P. Raised pro-inflammatory cytokines interleukin 6 and tumour necrosis factor $\alpha$ in coeliac disease mucosa detected by immunohistochemistry. Gut 1994; 35: 1398-404.

10 Lundin K, Scott H, Hansen T, Paulsen G, Halstensen TS, Fausa $\mathrm{O}$, et al. Gliadin specific, HLA-DQ $\left(\alpha 1^{\star} 0501\right.$, $\left.\beta 1^{\star} 0201\right)$ restricted $T$ cells isolated from the small intestinal mucosa of coeliac disease patients. $\mathcal{F}$ Exp Med 1993; 178: 187-96.

11 Przemioslo R, Lundin K, Sollid L, Nelufer J, Ciclitira P. Histological changes in small bowel mucosa induced by gliadin sensitive T lymphocytes can be blocked by antiinterferon $\gamma$ antibody. Gut 1995; 36: 874-9.

12 Walker-Smith J, Guandalini S, Schmitz J, Schmerling D, Visakorpi J. Revised criteria for diagnosis of coeliac disease. Arch Dis Child 1990; 65: 909-11.

13 Kontakou M, Przemioslo R, Sturgess R, Limb GA, Ellis HJ, Day $P$ et al. Cytokine mRNA expression in the mucosa of treated coeliac patients after wheat peptide challenge. Gut 1995; 37: 52-7.

14 Mosmann T, Coffman R. TH1 and TH2 cells: different patterns of lymphokine secretion lead to different functional properties. Annu Rev Immunol 1989; 7: 145-73.

15 Moore K, O'Garra A, Malefyt RdW, Mosmann T. Interleukin 10. Annu Rev Immunol 1993; 11: 165-90.
16 Mowat A, Widmer M. A role for IL-4 in immunologically mediated enteropathy. Clin Exp Immunol 1995; 99: 65-9.

17 Kuhn R, Rajewsky K, Muller W. Generation and analysis of interleukin-4 deficient mice. Science 1991; 254: of interleul

18 Neissner M, Volk B. Altered Th1/Th2 cytokine profiles in the intestinal mucosa of patients with inflammatory bowe disease as assessed by quantitative reversed transcribed polymerase chain reaction (RT-PCR). Clin Exp Immunol 1995; 101: 428-35.

19 Kucharzik $T$, Stoll $R$, Lugering $N$, Domschke W. Circulating anti-inflammatory cytokine IL-10 in patients with inflammatory bowel disease (IBD). Clin Exp Immunol 1995; 100: 452-6.

20 Schreiber S, Heinig $T$, Thiele $H$, Raedler A. Immunoregulatory role of interleukin 10 in patients with inflammatory bowel disease. Gastroenterology 1995; 108: matory $1434-44$.

21 Schreiber S, Heinig T, Panzer U, Reinking R, Bouchaed A Stahl PD, et al. Impaired response of activated mononuclear phagocytes to interleukin 4 in inflammatory bowe disease. Gastroenterology 1995; 108: 21-33.

22 Stensen W. Interleukin-4 hyporesponsiveness in inflammatory bowel disease: Immune defect or physiological response? Gastroenterology 1995; 108: 284-6.

23 Nilsen E, Lundin K, Krajci P, Scott H, Sollid L, Brandtzaeg P. Gluten specific, HLA-DQ restricted T cells from coeliac mucosa produce cytokines with Thl or Th0 profile dominated. Gut 1995; 37: 766-77.

24 Nilsen E, Gjertsen H, Jensen K, Brandtzaeg P, Lundin $K$ Gluten activation of peripheral blood $T$ cells induces a Th0-like cytokine pattern in both coeliac patients and controls. Clin Exp Immunol 1996; 103: 295-303.

25 Soloway P Fish S, Passmore H, Gefter M, Coffe R, Manser T. Regulation of the immune response to peptide Manser T. Regulation of the immune response to peptide antigens: differential induction of immediate-type hypersensitivity and T-cell proliferation due to changes in either peptide structure or major histocompatibi

26 Murray JS, Madri J, Tite J, Carding SR, Bottomly K. MHC control of $\mathrm{CD} 4+\mathrm{T}$ cell subset activation. $\mathcal{f}$ Exp Med 1989; 170: $2135-40$. 